\title{
Problems faced by online customers - A Garret Ranking Approach
}

\author{
S. Ramesh ${ }^{\mathrm{a}}$ and A. Senthil Kumar ${ }^{\mathrm{a}^{*}}$
}

${ }^{a}$ School of Commerce Studies, Jain (Deemed-to-be) University, Bengaluru, Karnataka 560069, India

\begin{tabular}{l}
\hline C H R O N I C L E \\
\hline Article history: \\
Received: October 29, 2018 \\
Received in revised format: No- \\
vember 19, 2018 \\
Accepted: January 10, 2019 \\
Available online: \\
January 10, 2019 \\
\hline Keywords: \\
Online customers \\
Garret ranking \\
Online purchase \\
Fake website \\
Faulty product \\
Product variation
\end{tabular}

\begin{abstract}
The development in internet technologies provides various innovative business opportunities and creates competitiveness among the electronic marketers in online marketing. The satisfaction of customers in e-purchase depends on various problems and facilities which are prevailing in the online market. The study was conducted with the aim of analyzing and ranking the problems of customers in online purchase. The study also examined the relationship between the demographic variables and problems faced by online customers. The data was collected from 512 online customers who are living in Bengaluru city, Karnataka through questionnaires during the month of August 2018. Garret ranking was used to find out the ranking distribution pattern of customers in online purchase. The problems 'product variation' and 'faulty products' have been quoted as the major problems faced by the online customers irrespective of the demographic their profile. The ranking pattern of the third major problem 'delay in delivery' differs with respect to education and customers' income. The ranking pattern for the problem 'fake website' was significantly different with respect to gender, age and education of customers.
\end{abstract}

C 2019 by the authors; licensee Growing Science, Canada

\section{Introduction}

Internet and its upcoming technologies play a key role in all organizations for developing business and marketing strategy and also influencing corporate strategy as well. The growing use of Internet in India provides distinct opportunities for online shopping from both customer and seller perspective (SepehriRad et al., 2019). A sizeable number of studies have been examined in customers' problems in online marketing. Each day business strategies and marketing technologies are being transformed and consumers are also coping up with those changes. Hence, it is necessary to examine the consumers' behaviors periodically whenever new technology emerges in online marketing. Consumers' emotional response towards online purchase may affect them to visit the website again. The factors affecting the intention to return to a website are the enjoyment of the shopping experience and the usefulness of the web site (Mohan Kumar \& Shiva Shanthi, 2016). E-commerce merchants are trying to satisfy their customers in all aspects such as product quality, delivery of product chosen by the consumers, time on delivery, method of payment, complete information about the company and product, return of goods, packing etc. However, few e-commerce merchants are involved in fraudulent activities because of

* Corresponding author.

E-mail address: senthilvisangm@gmail.com (A. Senthil Kumar)

C 2019 by the authors; licensee Growing Science, Canada doi: $10.5267 /$ j.msl.2019.1.005 
unawareness of customers in most of the online activities including latest technologies by the majority of consumers (Mallik et al., 2019). The perception of customers and their satisfaction in online shopping depends on various factors associated with it. If the sellers of online markets know the factors influencing the consumer behavior in online purchase, they can take the necessary initiative to develop their corporate and marketing strategies for converting potential customers into active customers without changing their original customer base (Raunaque et al., 2016). This research will help in finding the factors influencing the buying behavior of consumers on online marketing. The study will further encompass to equip the online marketers more profitable and which helps to add value in the existing services (Asareh \& Ghaeli, 2013; Aghaei \& Naeini, 2018).

\section{Review of Literature}

A research study conducted by Kumar and Dange (2012) revealed that the factors like service quality, privacy and security control, brand/reputation, delivery/logistic, after sales services and incentive influence the consumer behavior on online marketing. Internal factors viz. demographic, socio-economic, technology, marketing etc. and external factors viz. perception, motivation, self-image, attitude etc. influence buying motives of online consumer (Grabowski, 2014). The attributes that influence the customer to buy through online are friendliness of the website, cash on delivery, discounts and offers, gateway in online transaction and free shipping (Mohan Kumar \& Shiva Shanthi, 2016). Vaghela (2014) found that most of the customers were perceived that online shopping is better option than manual shopping and most of the customers were satisfied with their online shopping transactions. Factors such as provision of order \& product arrival information, online payment security, chat room functions, easy to operate search engines, comparison, complete information about the product etc. determines the success of online market (Omar et al., 2011; Naway \& Rahmat, 2019).

According to Cho and Park (2001) and Park and Kim (2006) there is a difference in China and other developed countries with regard to payment methods. The new marketing concept is one of the most important factors the customers think and agree to reduce their time and energy (Raunaque et al., 2016; Omar et al., 2011). The research by Cao et al. (2018) found that customer satisfaction of online shoppers can be partially predicted by post-purchase activities such as shipping service and tracking. Demographic variables of age and income were found to negatively impact customer satisfaction of online shoppers from Taiwan. Consumers' online shopping experiences may be improved by incentive programs like point-and incentive-based premium, saved shopping lists, gift and cumulative discounts (Breitenbach \& Van Doren, 1998). Consumers' fundamental shopping orientations have no significant impact on their proclivity to purchase products online. Factors that are more likely to influence purchase intention include prior purchase, product type, and gender (Zhou et al., 2017; Brown et al., 2003).

Many organizations in India have started to use the Internet for their business with the aim of cutting marketing costs, wide reach of consumers, taking competitive advantage by reducing the price of their products and services. Marketers also use the Internet to communicate and disseminate information for selling their products, to obtain feedback and also to conduct satisfaction surveys with customers. Customers use the internet not only to buy the product online, but also to compare prices, product features, check the buyers reviews and after sale service facilities etc., towards on line marketing. Many experts are optimistic about the prospect of online marketing.

In addition to the tremendous potential of the online market, the Internet provides a unique opportunity for marketers to more efficiently reach existing and potential customers. Researchers and practitioners of online market constantly strive to gain an improved insight into consumer behavior in cyberspace. Customers face different problems that affect their buying decision (Grabowski, 2014). This study concentrates to examine the ranking pattern of various problems which are currently faced by the online buyers. 


\section{Objectives}

The study was conducted with the following objectives:

1 To analyze the problems of consumers in online purchase.

2 To rank the problems faced by online customers.

3 To examine the relationship between the demographic variables and problems faced by online customers.

\section{Hypotheses}

The following null hypothesis has been framed to achieve the objectives of the study.

$\mathrm{H}_{0}$ : The ranking pattern of each of different problems does not differ with demographic profile of the online customers.

\section{Research Methodology}

The customers satisfaction towards purchasing of goods and services in online marketing depends on various factors such as delivery of correct product, trust on e-commerce seller, details of product information available in the website, secured payment mechanism, return back policy, on time delivery of product and facilities offered by the seller etc. which are prevailing in the online market. In order to meet the study objectives, totally 600 questionnaires were distributed among online customers who are living in Bengaluru city, Karnataka by employing convenience sampling method. This study focuses on understanding the problems faced by the customers while buying the items in e-commerce websites considering a particular geographical area. The data for the questionnaire were collected through offline as well as online mode using Google forms in Google Docs during the month of August 2018. Among all, only 512 questionnaires were complete in all aspects which are considered for the study. Capital city of Karnataka state is chosen as the study area. With relevance to the research questions and the hypothesis framed, Garret ranking was used to find out the problems which will mostly affect the customers in online purchase and bring out the relationship between the demographic variables such as age, income, gender, occupation, marital status, education level, residential area and ranking of factors. SPSS Version 22 was used for data analysis.

\section{Data Analysis and Interpretation}

There are many factors which affect the consumer behavior in online purchase and marketing. This study analyses the problems faced by the consumer in online purchase.

Table 1

Garret Ranking

\begin{tabular}{|c|c|c|c|c|c|c|c|c|c|c|}
\hline \multirow{2}{*}{$\begin{array}{l}\text { Sl. } \\
\text { No. }\end{array}$} & \multirow{2}{*}{ Factors } & \multicolumn{7}{|c|}{ Rank } & \multirow{2}{*}{$\begin{array}{l}\text { Garret } \\
\text { Score }\end{array}$} & \multirow{2}{*}{ Rank } \\
\hline & & 1 & 2 & 3 & 4 & 5 & 6 & 7 & & \\
\hline 1 & Product Variation & 119 & 41 & 26 & 17 & 4 & 3 & 2 & 69.599 & 1 \\
\hline 2 & Faulty Products & 37 & 58 & 74 & 16 & 14 & 7 & 6 & 60.071 & 2 \\
\hline 3 & Delay in Delivery & 7 & 21 & 48 & 44 & 42 & 27 & 23 & 47.557 & 3 \\
\hline 4 & Return Back & 12 & 29 & 25 & 39 & 33 & 49 & 25 & 46.448 & 4 \\
\hline 5 & Unable to read information in Website & 10 & 38 & 17 & 33 & 44 & 36 & 34 & 45.976 & 5 \\
\hline 6 & Fake Website & 21 & 18 & 12 & 44 & 37 & 45 & 35 & 45.222 & 6 \\
\hline 7 & Payment Problems & 6 & 7 & 10 & 19 & 38 & 45 & 87 & 35.127 & 7 \\
\hline
\end{tabular}

Table 1 shows the respondents' ranking for the seven factors which are mostly confronted by the online buyers at present. It is observed from Table 1 that majority of the respondents have chosen to give rank 1 to the factor 'Product Variation', followed by 'Faulty products' (rank-2) and Delay in Delivery (rank- 
3). The respondents have assigned the least rank to the factor 'Payment problems'. The factors delay in delivery and return back the items are ranked third and fourth, respectively.

In order to see if there is any difference in the ranking of factors of problems faced by online customers of male and female respondents, Mann-Whitney U Test was carried out with the null hypothesis of no difference in the ranking pattern of male and female respondents and the results are shown in the Table 2 . It can be noted from the Table 2 that very small values of $Z$ value and very high values of $p(>.05)$ for all the factors of problems faced by the online customers (except 'unable to read information in website' and 'fake website') verify that there is no sufficient evidence to reject the null hypotheses and it is concluded that the distribution of ranking pattern is the same among male and female customers on various problems faced them. However, the high $\mathrm{Z}$ value and low $\mathrm{p}$-value $(<.05)$ for the problem Fake website and $\mathrm{p}<.10$ for the problem unable to read information in website signify that there is a significant difference in the ranking pattern of these problems by male and female customers.

Table 2

Results of Mann-Whitney U Test - Gender Vs Ranking of Factors

\begin{tabular}{|c|c|c|c|c|c|}
\hline \multirow[t]{2}{*}{ Problems } & \multicolumn{2}{|c|}{$\begin{array}{l}\text { Mean Ranks - } \\
\text { Gender }\end{array}$} & \multirow[t]{2}{*}{ Mann-Whitney U } & \multirow[t]{2}{*}{ Z } & \multirow[t]{2}{*}{ p-value } \\
\hline & Female & Male & & & \\
\hline Delay in delivery & 106.32 & 106.64 & 5529.000 & -.039 & 0.484 \\
\hline Faulty products & 106.88 & 106.19 & 5510.000 & -.084 & 0.466 \\
\hline Product variation & 109.51 & 104.11 & 5263.500 & -.706 & 0.240 \\
\hline Return back & 109.84 & 103.84 & 5232.500 & -.717 & 0.237 \\
\hline Unable to read information in website & 113.59 & 100.86 & 4880.000 & -1.523 & $0.064 * *$ \\
\hline Fake website & 98.18 & 113.13 & 4763.500 & -1.791 & $0.037^{*}$ \\
\hline Payment problems & 101.90 & 110.17 & 5113.500 & -1.019 & 0.154 \\
\hline
\end{tabular}

* Significant at 5 per cent level of significance

** Significant at 10 per cent level of significance

In order to see if there is any difference in the ranking of problems faced by online customers in different age groups, Kruskal Wallis Test was carried out with the null hypothesis of no difference in the ranking pattern of customers in different age groups and the results are shown in Table 3. It can be observed from the Table 3 that very small values of chi-square and very high values of $p(>.05)$ for all the problems (except fake website) verify that there is no sufficient evidence to reject the null hypotheses and it is concluded that the distribution of ranking pattern (except fake website) is same among customers in different age groups on various problems. However, the high Chi-Square value and low $\mathrm{p}$-value $(<.05)$ for the problem 'fake website' signify that there was a significant difference in the ranking pattern of these problems by different age groups.

Table 3

Results of Kruskal Wallis Test - Age Vs Ranking of Problems

\begin{tabular}{|c|c|c|c|c|c|c|c|c|}
\hline \multirow[b]{2}{*}{ Problems } & \multicolumn{5}{|c|}{ Mean Ranks - Age (in years) } & \multirow{2}{*}{$\begin{array}{l}\text { Chi- } \\
\text { Square }\end{array}$} & \multirow[b]{2}{*}{ df } & \multirow{2}{*}{$\begin{array}{c}\text { Asymp. } \\
\text { Sig. }\end{array}$} \\
\hline & $\begin{array}{c}\text { Below } \\
20\end{array}$ & $20-30$ & $30-40$ & $40-50$ & $\begin{array}{l}\text { Above } \\
50\end{array}$ & & & \\
\hline Delay in delivery & 95.90 & 108.85 & 110.14 & 110.74 & 117.96 & 3.191 & 4 & .526 \\
\hline Faulty products & 109.63 & 105.75 & 95.15 & 128.54 & 96.62 & 5.396 & 4 & .249 \\
\hline Product variation & 108.31 & 98.92 & 107.07 & 111.04 & 116.66 & 2.291 & 4 & .682 \\
\hline Return back & 101.67 & 111.65 & 107.71 & 99.17 & 110.28 & 1.322 & 4 & .858 \\
\hline $\begin{array}{l}\text { Unable to read information in } \\
\text { website }\end{array}$ & 120.48 & 93.68 & 105.44 & 114.09 & 99.16 & 7.028 & 4 & .134 \\
\hline Fake website & 98.58 & 122.70 & 113.90 & 70.80 & 106.52 & 14.327 & 4 & $.006^{*}$ \\
\hline Payment problems & 110.84 & 100.25 & 100.54 & 115.52 & 112.10 & 2.226 & 4 & .694 \\
\hline
\end{tabular}

In order to examine the difference in the ranking pattern of problems faced by online customers with different occupation, the null hypothesis of no difference in the ranking pattern of customers in different occupation was framed and the results are shown in Table 4. 
Table 4

Results of Kruskal Wallis Test - Occupation Vs Ranking of Problems

\begin{tabular}{lrrrrrrrr}
\hline \multicolumn{1}{c}{ Problems } & \multicolumn{3}{c}{ Occupation } & & Chi- & Delf \\
\cline { 2 - 7 } & $\begin{array}{c}\text { Profes- } \\
\text { sional }\end{array}$ & Salaried & $\begin{array}{c}\text { Self } \\
\text { Employed }\end{array}$ & Student & $\begin{array}{c}\text { Home } \\
\text { Maker }\end{array}$ & $\begin{array}{c}\text { Asymp. } \\
\text { Square }\end{array}$ & Df. \\
\hline Delay in delivery & 104.27 & 105.85 & 110.14 & 104.37 & 117.31 & .695 & 4 & .952 \\
Faulty products & 112.80 & 99.42 & 95.15 & 115.34 & 101.85 & 4.124 & 4 & .389 \\
Product variation & 117.34 & 104.38 & 107.07 & 102.59 & 96.58 & 2.515 & 4 & .642 \\
Return back & 98.69 & 117.35 & 107.71 & 102.12 & 106.42 & 2.829 & 4 & .587 \\
Unable to read infor- & 120.85 & 98.87 & 105.44 & 102.70 & 111.54 & 3.696 & 4 & .449 \\
mation in website & 94.66 & 109.91 & 113.90 & 102.32 & 132.85 & 5.187 & 4 & .269 \\
Fake website & 101.66 & 106.86 & 100.54 & 117.46 & 83.08 & 5.014 & 4 & .286 \\
\hline Payment problems & & & & & & & & \\
\hline
\end{tabular}

In Table 4, $(p>.05)$ for all the problems verify that there is no sufficient evidence to reject the null hypotheses and it is concluded that the distribution of ranking pattern is same among respondents with different occupation on various problems.

Table 5

Results of Kruskal Wallis Test - Marital Status Vs Ranking of Problems

\begin{tabular}{|c|c|c|c|c|c|c|c|}
\hline \multirow{2}{*}{ Problems } & \multicolumn{4}{|c|}{ Marital Status } & \multirow{2}{*}{$\begin{array}{c}\text { Chi- } \\
\text { Square }\end{array}$} & \multirow{2}{*}{ df } & \multirow{2}{*}{$\begin{array}{c}\text { Asymp. } \\
\text { Sig. }\end{array}$} \\
\hline & Unmarried & Married & Widow & Separated & & & \\
\hline Delay in delivery & 106.74 & 106.80 & 83.88 & 109.63 & .599 & 3 & .897 \\
\hline Faulty products & 108.79 & 102.16 & 167.75 & 103.42 & 4.995 & 3 & .172 \\
\hline Product variation & 105.78 & 103.21 & 117.88 & 135.63 & 3.860 & 3 & .277 \\
\hline Return back & 114.38 & 101.14 & 72.25 & 98.50 & 3.918 & 3 & .270 \\
\hline $\begin{array}{l}\text { Unable to read information in } \\
\text { website }\end{array}$ & 105.73 & 108.57 & 105.00 & 96.17 & .485 & 3 & .922 \\
\hline Fake website & 98.72 & 114.25 & 72.75 & 116.71 & 4.827 & 3 & .185 \\
\hline Payment problems & 107.14 & 107.46 & 108.13 & 92.83 & .692 & 3 & .875 \\
\hline
\end{tabular}

The high $\mathrm{p}$ value $(>.05)$ for all the problems found in Table 5 verify that there is no significant difference in the ranking pattern of married and unmarried respondents on various problems faced by them.

Table 6

Results of Kruskal Wallis Test - Educational Level Vs Ranking of Problems

\begin{tabular}{|c|c|c|c|c|c|c|c|}
\hline \multirow[b]{2}{*}{ Problems } & \multicolumn{4}{|c|}{ Educational Level } & \multirow{2}{*}{$\begin{array}{c}\text { Chi- } \\
\text { Square }\end{array}$} & \multirow[b]{2}{*}{ df } & \multirow{2}{*}{$\begin{array}{c}\text { Asymp. } \\
\text { Sig. }\end{array}$} \\
\hline & $\begin{array}{l}\text { Up to } \\
\text { HSC }\end{array}$ & $\begin{array}{l}\text { Diploma / } \\
\text { ITI }\end{array}$ & UG/PG & $\begin{array}{l}\text { Profes- } \\
\text { sional }\end{array}$ & & & \\
\hline Delay in delivery & 117.07 & 118.91 & 83.28 & 96.84 & 13.363 & 3 & $.004 *$ \\
\hline Faulty products & 101.44 & 102.29 & 117.11 & 107.63 & 2.449 & 3 & .485 \\
\hline Product variation & 116.36 & 104.98 & 92.03 & 118.37 & 6.663 & 3 & $.083 * *$ \\
\hline Return back & 118.92 & 95.65 & 120.71 & 89.53 & 9.978 & 3 & $.019 *$ \\
\hline $\begin{array}{l}\text { Unable to read information in } \\
\text { website }\end{array}$ & 112.09 & 106.79 & 110.51 & 89.84 & 3.019 & 3 & .389 \\
\hline Fake website & 91.69 & 116.13 & 95.01 & 125.90 & 10.129 & 3 & $.018 *$ \\
\hline Payment problems & 101.26 & 100.78 & 113.70 & 117.42 & 3.004 & 3 & .391 \\
\hline
\end{tabular}

* Significant at 5 per cent level of significance

** Significant at 10 per cent level of significance

Online trust is essential in building any relationship with customers. Customers are focusing on retail giants Amazon, Flipkart, Snapdeal and Paytm mall and they are shopping all types of products. They do not apply the same level of trust to small merchants. There seems to be however a diminishing trust in online merchants (Wiebke Reile, 2017). 
Table 7

Results of Kruskal Wallis Test - Income Vs Ranking of Problems

\begin{tabular}{|c|c|c|c|c|c|c|c|c|c|}
\hline \multirow{2}{*}{ Problems } & \multicolumn{6}{|c|}{ Income } & \multirow[t]{2}{*}{$\begin{array}{c}\text { Chi- } \\
\text { Square }\end{array}$} & \multirow[t]{2}{*}{ df } & \multirow[t]{2}{*}{$\begin{array}{c}\text { Asymp. } \\
\text { Sig. }\end{array}$} \\
\hline & Below 10 & $10-20$ & $20-30$ & $30-40$ & $40-50$ & $\begin{array}{l}\text { Above } \\
50\end{array}$ & & & \\
\hline Delay in delivery & 69.10 & 118.43 & 123.24 & 108.65 & 116.84 & 87.95 & 17.286 & 5 & $.004^{*}$ \\
\hline Faulty products & 91.77 & 108.00 & 107.38 & 110.06 & 101.28 & 116.47 & 2.898 & 5 & .716 \\
\hline Product variation & 110.92 & 112.20 & 102.57 & 103.06 & 113.79 & 98.63 & 2.172 & 5 & .825 \\
\hline Return back & 102.00 & 108.61 & 92.54 & 114.63 & 102.41 & 116.05 & 3.986 & 5 & .551 \\
\hline $\begin{array}{l}\text { Unable to read infor- } \\
\text { mation in website }\end{array}$ & 124.33 & 101.54 & 115.63 & 99.01 & 105.23 & 100.82 & 4.184 & 5 & .523 \\
\hline Fake website & 120.42 & 88.80 & 109.49 & 110.06 & 103.49 & 106.26 & 4.047 & 5 & .543 \\
\hline Payment problems & 109.75 & 106.25 & 108.79 & 101.15 & 103.24 & 114.82 & 1.311 & 5 & .934 \\
\hline
\end{tabular}

When an online business gives accurate information about the products and the ability to see the product picture as per the customers' requirements, it gives the client an accurate expectation of the product. Due to less information presented to consumers, they lose the inability to evaluate the quality of the product. It can also be found from the Table 6 that the problems 'delay in delivery', 'return back', 'product variation' and 'fake website' are significantly different with the distribution of ranking pattern among customers with different qualification on various problems faced by them. The very small values of chi-square and very high values of $\mathrm{p}(>.05)$ for all the problems (except 'delay in delivery') found in Table 7 verify that there was no significant difference in the distribution of ranking by customers with different income groups on various problems faced during online purchase. The ranking pattern of the problem 'delay in delivery' is significantly different among customers in different income groups.

Table 8

Results of Kruskal Wallis Test - Residential Area Vs Ranking of Problems

\begin{tabular}{|c|c|c|c|c|c|c|c|}
\hline \multirow[b]{2}{*}{ Problems } & \multicolumn{4}{|c|}{ Residential area } & \multirow[b]{2}{*}{$\begin{array}{l}\text { Chi- } \\
\text { Square }\end{array}$} & \multirow[b]{2}{*}{$\mathrm{df}$} & \multirow{2}{*}{$\begin{array}{l}\text { Asymp. } \\
\text { Sig. }\end{array}$} \\
\hline & Metro & Urban & $\begin{array}{c}\text { Semi } \\
\text { Urban }\end{array}$ & Rural & & & \\
\hline Delay in delivery & 114.05 & 113.19 & 93.01 & 88.29 & 6.239 & 3 & .101 \\
\hline Faulty products & 103.50 & 104.62 & 112.94 & 108.08 & .866 & 3 & .834 \\
\hline Product variation & 110.61 & 103.93 & 107.36 & 97.58 & 1.063 & 3 & .786 \\
\hline Return back & 95.16 & 116.22 & 104.15 & 121.58 & 5.644 & 3 & .130 \\
\hline Unable to read information in website & 108.91 & 99.07 & 113.94 & 104.50 & 1.936 & 3 & .586 \\
\hline Fake website & 109.70 & 108.43 & 96.03 & 114.58 & 2.119 & 3 & .548 \\
\hline Payment problems & 105.41 & 100.83 & 116.45 & 105.13 & 2.118 & 3 & .548 \\
\hline
\end{tabular}

The high values of $\mathrm{p}(>.05)$ found in Table 8 for all the problems verify that there was no significant difference in the distribution of ranking pattern of customers with respect to their residential area on various problems faced by them.

\section{Conclusion and Scope for further Studies}

The problems 'product variation' and 'faulty products' have been quoted as the major problems faced by the online customers irrespective of their demographic profile. The ranking pattern of the third major problem 'delay in delivery' differs with respect to education and income of customers. The ranking pattern of the problem 'return back' was significantly different with respect to customers' education. The ranking pattern of the problem 'unable to read information in website' was significantly different with respect to male and female customers. The ranking pattern for the problem 'fake website' was significantly different with respect to gender, age and education of customers. The study will further encompass the various inputs which will equip the e-marketers for building online marketing more 
lucrative, adopt suitable measures for satisfying the online customers by their services and simultaneously increase their market share. Consumers should be educated on online shopping procedures and purchase with secured online payments. Government should also strengthen the e-commerce trading by implementing suitable cyber law to protect the consumers from fake merchants/websites in online purchasing. Further research may be conducted to explore the effects of culture on e-commerce website design and customer satisfaction of online products or services.

\section{Acknowledgement}

The authors would like to thank the anonymous referees for constructive comments on earlier version of this paper.

\section{References}

Aghaei, S \& Naeini, A. (2018). Consumer attitudes toward new pasta products in Iran market: A qualitative and quantitative study. Management Science Letters, 8(2), 109-120.

Asareh, B \& Ghaeli, M. (2013). Valuation and assessment of customers in banking industry using data mining techniques. International Journal of Data and Network Science, 3(2), 93-102.

Breitenbach, C. and Van Doren, D. (1998). Value-added marketing in the digital domain: enhancing the utility of the Internet, Journal of Consumer Marketing, 15(6), 558-575.

Brown, M., Pope, N., \& Voges, K. (2003). Buying or browsing? An exploration of shopping orientations and online purchase intention. European Journal of Marketing, 37(11/12), 1666-1684.

Cao, Y., Ajjan, H., \& Hong, P. (2018). Post-purchase shipping and customer service experiences in online shopping and their impact on customer satisfaction: An empirical study with comparison. Asia Pacific Journal of Marketing and Logistics, 30(2), 400-416.

Cho, N. and Park, S. (2001). Development of electronic commerce user-consumer satisfaction index (ECUSI) for internet shopping, Industrial Management \& Data Systems, 101(8), 400-406.

Grabowski, P. (2014). Key factors influencing online consumer behaviour-backed by research. eCommerce insiders.

Kumar, V., \& Dange, U. (2012). A study of factors affecting online buying behavior: A conceptual model. DOI:10.2139/ssrn.2285350.

Mallik, A., Ahsan, A., Shahadat, M \& Tsou, J. (2019). Man-in-the-middle-attack: Understanding in simple words. International Journal of Data and Network Science, 3(2), 77-92.

Mohan Kumar, T.P., \& Shiva Shanthi, S. (2016), Consumer behavior towards online marketing International Journal of Applied Research, 2(5), 859-863.

Naway, F \& Rahmat, A. (2019). The mediating role of technology and logistic integration in the relationship between supply chain capability and supply chain operational performance. Uncertain Supply Chain Management, 7(3), 553-566.

Omar, M., Bathgate, I., \& Nwankwo, S. (2011). Internet marketing and customer satisfaction in emerging markets: the case of Chinese online shoppers. Competitiveness Review: An International Business Journal, 21(2), 224-237.

Park, C. and Kim, Y. (2006), The effect of information satisfaction and relational benefit on consumers' online shopping site commitments, Journal of Electronic Commerce in Organizations, 4(1), 70-91.

Raunaque, N., Zeeshan, M., \& Imam, M. A. (2016). Consumer Perception towards Online Marketing in India. International Journal of Advanced Engineering, Management and Science, 2(8), 12361240.

Sepehri-Rad, A., Sadjadi, S \& Sadi-Nezhad, S. (2019). An application of DEMATEL for transaction authentication in online banking. International Journal of Data and Network Science, 3(2), 71-76.

Vaghela, P. (2014). A study on consumer perception towards online shopping. International Journal of Marketing and Technology, 4(12), 200.

Wiebke Reile (2017), Factors Influencing Online Shopping Behavior of Consumers, Web Marketing, (May 1, 2017) https://www.searchfit.com/2017/05/01/factors-influencing-online-shopping-behavior-consumers/ 
Zhou, X., Song, Q., Li, Y. Y., Tan, H., \& Zhou, H. (2017). Examining the influence of online retailers' micro-blogs on consumers' purchase intention. Internet Research, 27(4), 819-838.

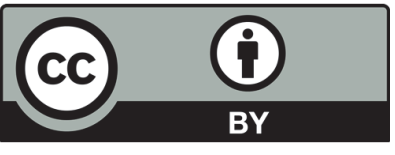

(C) 2019 by the authors; licensee Growing Science, Canada. This is an open access article distributed under the terms and conditions of the Creative Commons Attribution (CC-BY) license (http://creativecommons.org/licenses/by/4.0/). 